\title{
THE RELATIONSHIP BETWEEN GOVERNMENT EXPENDITURES, ECONOMIC GROWTH AND INFLATION IN OECD COUNTRIES ${ }^{1}$ OECD ÜLKELERINDE HÜKÜMET HARCAMALARI, EKONOMIKK BÜYÜME VE ENFLASYON ARASINDAKİ İLIŞKİ
}

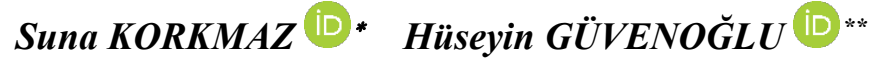

Araştırma Makalesi / Geliş Tarihi: 13.08.2021

Kabul Tarihi: 30.09 .2021

\begin{abstract}
Governments will want to achieve their highest priority goal according to their economic circumstances. Governments use many tools to achieve these goals. Economic growth and price stability are among the main objectives which fall within the scope of governments. One of the most important tools that governments will deploy to achieve these goals government expenditures, which is a fiscal policy tool. In this study, the relationship between government expenditures, economic growth and inflation in 9 randomly selected OECD countries (France, Germany, Italy, UK, Portugal, Hungary, Spain, Finland and Poland) was analyzed by panel causality method using annual data for the period 2010-2019. As a result of the analysis, a bidirectional causality relationship was found between economic growth and inflation in the period analyzed. It was also found that there was a unidirectional causality relationship from inflation to government expenditures and from government expenditures to economic growth.
\end{abstract}

Keywords: Government Expenditure, Inflation, Economic Growth, Panel Causality Test

JEL Classification: C23, E31, H50, O47

$\ddot{\mathbf{O z}}$

Hükümetler, ekonomik koşulları doğrultusunda en yüksek önceliğe sahip hedeflerine ulaşmak isteyeceklerdir. Bu hedeflere ulaşmak isteyen hükümetler birçok araç kullanmaktadır. Ekonomik büyüme ve fiyat istikrarı hükümetlerin görev alanına giren temel hedefler arasında yer almaktadır. Hükümetlerin bu hedeflere ulaşmak için kullanacağı en önemli araçlardan biri maliye politikası aracı olan kamu harcamalarıdır. Bu çalışmada rassal olarak seçilen 9 OECD ülkesinde (Fransa, Almanya, İtalya, Birleşik Krallık, Portekiz, Macaristan, İspanya, Finlandiya ve Polonya) hükümet harcamaları, ekonomik büyüme ve enflasyon arasındaki ilişki 2010-2019 dönemine ait yıllık veriler kullanılarak panel nedensellik yöntemi ile analiz edilmiştir. Analiz sonucunda incelenen dönemde ekonomik büyüme ile enflasyon arasında çift yönlü bir nedensellik ilişkisi bulunmuştur. Ayrıca enflasyondan hükümet harcamasına doğru ve hükümet harcamasından da ekonomik büyümeye doğru tek yönlü bir nedensellik ilişkisi olduğu tespit edilmiştir.

Anahtar Kelimeler: Hükümet Harcamaları, Enflasyon, Ekonomik Büyüme, Panel Nedensellik Testi

JEL Sinıflaması: C23, E31, H50, O47

\footnotetext{
${ }^{1}$ Bibliyografik Bilgi (APA): FESA Dergisi, 2021; 6(3), 490-498 / DOI: 10.29106/fesa.982512

* Prof. Dr., Bandırma Onyedi Eylül University, Faculty of Economics and Administrative Sciences, Department of Economics, skorkmaz@,bandirma.edu.tr, Balıkesir - Turkey, ORCID: 0000-0001-6221-2322

${ }^{* *}$ Research Assistant Dr., Bandırma Onyedi Eylül University, Faculty of Economics and Administrative Sciences, Department of Economics, hguvenoglu@bandirma.edu.tr, Balıkesir - Turkey, ORCID: 0000-0002-5220-3657
} 


\section{Introduction}

Governments implement different policies to achieve their macroeconomic goals. There are two basic policy tools that they commonly use to achieve the targets they set, monetary and fiscal policy. As monetary and fiscal policies implemented by governments directly or indirectly affect macroeconomic targets such as economic growth, inflation, employment, etc., the changes in these policies are closely monitored by economic units. Monetary policies by central banks and fiscal policies by governments have very important effects to achieve economic goals. Which monetary and fiscal policies are more effective in achieving economic goals can vary depending on the conjectural structure of the economy and the relevant period. It is seen that the fiscal policies by governments, which cover public expenditures, taxes and transfer expenditures as a whole, stand out in certain periods in the economic system. Especially in times of economic crisis and recession, governments can turn to stimulate the economy with the expenditures they make. There is a constant change in the effectiveness of governments within the economic system. Due to this change, there can also be increases or decreases in government expenditures. As changes in government expenditure affect the macroeconomic indicators that stand out in the economy, such as economic growth and inflation, the role of government in the economy is also included in the economic literature as an important topic of discussion.

The discussion of how much the state should play an active role in the economic system is regarded as one of the main points on which Classical economists and Keynesian economists differ. Classical economists argue that a state should only intervene in the economy to a limited extent by fulfilling its basic duties such as health, safety, education and infrastructure services. They point out that the intervention of a state in the economic system could upset the general balance of the economy. They also express that a state does not function effectively and that the public sector's activity in the market would create an exclusionary effect on the private sector, and in this context, it will not be effective on economic output. The economists who adopted the Keynesian view argue that the state should intervene in the economy. With the Economic Depression in 1929, as the basic principles of the Classics failed to explain the crisis and failed to produce a solution to the economic problems experienced in this process, the views of the Classicals were abandoned and the views of Keynesian economics began to gain general acceptance. During that period, it has been observed that the economic depression process will come to an end with the governments implementing monetary and fiscal policies together. In this process, the view that the state should intervene in the economy, which is advocated by Keynesian economics, and the view that the economy can reach the full employment level and the amount of output in the economy will also be increased were accepted generally. Keynesian view was adopted in many developed and developing countries, especially in the 1950s and 1960s, in countries that adopted the concept of social state. The role of the public sector in the economic system increased significantly as a result of the expansionary fiscal policies implemented in many countries with the dominance of the Keynesian view adopted in those periods. Today, the governments of many countries apply monetary and fiscal policies in accordance with their economic conditions and intervene in the economy when necessary.

Governments use fiscal policy tools such as government expenditure, tax policies and transfer payments to achieve economic growth. Reviewing the economic literature, it is seen that the relationship between government expenditures and economic growth is mainly evaluated within the scope of two basic frameworks, Wagner law and Keynesian view. Wagner's law is expressed as "the law of the increasing expansion of the public and especially of state activities". According to this law, there is a relationship between government expenditure and economic growth. Wagner's law states that the growth of the public sector will occur as a result of economic growth. This sets forths that government expenditure is an intrinsic factor driven by economic growth. According to this view, the increase in government expenditure takes place as a result of economic growth. Whereas, according to the Keynesian view, economic growth occurs when government expenditure increases. In the Keynesian approach, an increase in government expenditures increases economic growth through the multiplier mechanism. This shows that government expenditure is an extrinsic factor that triggers economic growth. According to this approach, an increase in economic growth is the result of an increase in government expenditure (Loizides and Vamvoukas, 2005: 126; Thabane and Lebina, 2016: 87; Alqadi and Ismail, 2019: 1).

Government expenditures can effect inflation as well as economic growth. An increase in government expenditure will increase the demand for goods and services. The increase in demand for goods and services will increase the prices of goods and services. Accordingly, there will be an increase in the general level of prices in the economy. As a result of the increase in the prices of goods and services due to the increase in demand for goods and services, an inflation resulting from demand will be faced in the economy. In this case, the government will adopt a narrowing fiscal policy to control inflation arising from demand. This time it will reduce government expenditure, raise tax rates and lower transfer payments. An increase or decrease in government expenditures in an economy will also affect the macroeconomic indicators in that economy. Therefore, it is important how government expenditures affect economic growth and inflation, which are among macroeconomic indicators, and discussions continue on this issue in the economics literature. 


\section{Literature Review}

Reviewing the studies investigating the relationship between government expenditures, economic growth and inflation, it was seen that the findings vary according to the size of the public in the economy, the economic structure of the country, the relevant period, the empirical method applied, and the control variables used in the analysis. It was observed that some of the studies in the literature investigated the relationship between government expenditure and economic growth, some others the relationship between government expenditure and inflation, and in others, the relationship between government expenditure, economic growth and inflation. Literature studies on the subject are summarized in Table 1 .

Table 1. Literature Review

\begin{tabular}{|c|c|c|c|}
\hline Authors & Period / Country & Method & Results \\
\hline $\begin{array}{l}\text { Cheng and Lai } \\
\text { (1997) }\end{array}$ & $\begin{array}{l}\text { 1954-1994 } \\
\text { South Korea }\end{array}$ & $\begin{array}{l}\text { Granger causality } \\
\text { test }\end{array}$ & $\begin{array}{l}\text { They found a bidirectional causality } \\
\text { relationship between government } \\
\text { expenditure and economic growth. }\end{array}$ \\
\hline $\begin{array}{l}\text { Kolluri et al. } \\
\qquad(2000)\end{array}$ & $\begin{array}{l}\text { 1960-1993 } \\
\text { G7 countries }\end{array}$ & $\begin{array}{l}\text { Panel cointegration } \\
\text { test and ve VECM }\end{array}$ & $\begin{array}{l}\text { They determined that there is a } \\
\text { reciprocal causality relationship between } \\
\text { government expenditure and economic } \\
\text { growth in the long term. }\end{array}$ \\
\hline $\begin{array}{l}\text { Loizides and } \\
\text { Vamvoukas } \\
\quad(2005)\end{array}$ & $\begin{array}{c}\text { 1948-1995 } \\
\text { Greece } \\
\text { 1960-1995 } \\
\text { UK and Ireland }\end{array}$ & $\begin{array}{l}\text { Cointegration test } \\
\text { and Granger } \\
\text { causality test }\end{array}$ & $\begin{array}{l}\text { They reached findings that government } \\
\text { expenditure was the cause of economic } \\
\text { growth in the UK and Ireland in both the } \\
\text { short and long term, and that economic } \\
\text { growth in Greece was the cause of } \\
\text { government expenditure. }\end{array}$ \\
\hline $\begin{array}{l}\text { Sáez and Álvarez- } \\
\text { García } \\
\text { (2006) }\end{array}$ & $\begin{array}{c}\text { 1980-2002 } \\
15 \text { EU Countries }\end{array}$ & $\begin{array}{l}\text { Regression and } \\
\text { panel data analysis }\end{array}$ & $\begin{array}{l}\text { They found that government expenditure } \\
\text { positively affected economic growth. }\end{array}$ \\
\hline $\begin{array}{l}\text { Huang } \\
(2006)\end{array}$ & $\begin{array}{c}\text { 1979-2002 } \\
\text { China and Taiwan }\end{array}$ & $\begin{array}{l}\text { Bounds Test based } \\
\text { on UECM } \\
\text { estimation }\end{array}$ & $\begin{array}{l}\text { There is no long-term relationship } \\
\text { between government expenditure and } \\
\text { economic growth. }\end{array}$ \\
\hline $\begin{array}{l}\text { Jiranyakul and } \\
\text { Brahmasrene } \\
\quad(2007)\end{array}$ & $\begin{array}{l}\text { 1993:Q1-2006:Q4 } \\
\text { Thiland }\end{array}$ & $\begin{array}{l}\text { Granger causality } \\
\text { test and OLS } \\
\text { method }\end{array}$ & $\begin{array}{l}\text { They found that there is a unidirectional } \\
\text { causal relationship from government } \\
\text { expenditure to economic growth and that } \\
\text { government expenditure has a positive } \\
\text { and strong effect on economic growth. }\end{array}$ \\
\hline $\begin{array}{l}\text { Mohammad et al. } \\
\qquad(2009)\end{array}$ & $\begin{array}{l}\text { 1977-2007 } \\
\text { Pakistan }\end{array}$ & $\begin{array}{l}\text { Johansen } \\
\text { cointegration test }\end{array}$ & $\begin{array}{l}\text { They found that government expenditure } \\
\text { and inflation are negatively correlated } \\
\text { with economic growth in the long run. }\end{array}$ \\
\hline $\begin{array}{l}\text { Alexiou } \\
(2009)\end{array}$ & $\begin{array}{l}\text { 1995-2005 } \\
7 \text { transition countries } \\
\text { in Southeast Europe }\end{array}$ & Panel data analysis & $\begin{array}{l}\text { He found that government expenditure } \\
\text { had a strong and positive effect on } \\
\text { economic growth. }\end{array}$ \\
\hline $\begin{array}{l}\text { Taban } \\
(2010)\end{array}$ & $\begin{array}{l}\text { 1987:Q1-2006:Q4 } \\
\text { Turkey }\end{array}$ & $\begin{array}{l}\text { MWALD Granger } \\
\text { causality test }\end{array}$ & $\begin{array}{l}\text { There is a bidirectional causality } \\
\text { relationship between total government } \\
\text { expenditure and economic growth. }\end{array}$ \\
\hline
\end{tabular}




\begin{tabular}{|c|c|c|c|}
\hline Authors & Period / Country & Method & Results \\
\hline $\begin{array}{l}\text { Bashir et al. } \\
\qquad(2011)\end{array}$ & $\begin{array}{l}1972-2010 \\
\text { Pakistan }\end{array}$ & $\begin{array}{l}\text { Granger causality } \\
\text { test }\end{array}$ & $\begin{array}{l}\text { They found that there is a bidirectional } \\
\text { relationship between economic growth } \\
\text { and inflation, and a unidirectional causal } \\
\text { relationship from government } \\
\text { expenditure to inflation and from } \\
\text { economic growth to government } \\
\text { expenditure. }\end{array}$ \\
\hline $\begin{array}{l}\text { Olayungbo } \\
\text { (2013) }\end{array}$ & $\begin{array}{c}\text { 1970-2010 } \\
\text { Nigeria }\end{array}$ & VAR model & $\begin{array}{c}\text { A unidirectional causality relationship } \\
\text { was found extending from low } \\
\text { government expenditure to high } \\
\text { inflation. }\end{array}$ \\
\hline $\begin{array}{l}\text { Attari and Javed } \\
\qquad(2013)\end{array}$ & $\begin{array}{l}\text { 1980-2010 } \\
\text { Pakistan }\end{array}$ & $\begin{array}{l}\text { Granger causality } \\
\text { test }\end{array}$ & $\begin{array}{l}\text { They found that there is an unidirectional } \\
\text { causality relationship between } \\
\text { government expenditure and economic } \\
\text { growth, and between inflation and } \\
\text { economic growth. }\end{array}$ \\
\hline $\begin{array}{c}\text { Ono } \\
(2014)\end{array}$ & $\begin{array}{c}\text { 1960-2010 } \\
\text { Japan }\end{array}$ & ARDL analysis & $\begin{array}{l}\text { Ono found that economic growth } \\
\text { affected government expenditure. }\end{array}$ \\
\hline $\begin{array}{l}\text { Frank et al. } \\
\qquad(2014)\end{array}$ & $\begin{array}{c}\text { 1970-2010 } \\
\text { Ghana }\end{array}$ & $\begin{array}{l}\text { ARDL analysis and } \\
\text { Granger causality } \\
\text { test }\end{array}$ & $\begin{array}{l}\text { They found that government expenditure } \\
\text { has a statistically significant and positive } \\
\text { effect on economic growth in the long } \\
\text { term and a negative effect in the short } \\
\text { term. They did not find any causal } \\
\text { relationship between government } \\
\text { expenditure and economic growth. }\end{array}$ \\
\hline $\begin{array}{l}\text { Lahirushan and } \\
\text { Gunasekara } \\
\text { (2015) }\end{array}$ & $\begin{array}{c}1970-2013 \\
9 \text { Asian countries }\end{array}$ & Panel causality test & $\begin{array}{l}\text { They found a bidirectional causality } \\
\text { relationship between government } \\
\text { expenditure and economic growth. }\end{array}$ \\
\hline $\begin{array}{l}\text { Mehrara and } \\
\text { Sujoud } \\
(2015)\end{array}$ & $\begin{array}{l}\text { 1959-2010 } \\
\text { Iran }\end{array}$ & $\begin{array}{l}\text { Bayesyen } \\
\text { econometric } \\
\text { method }\end{array}$ & $\begin{array}{l}\text { They revealed that the increase in } \\
\text { government expenditure and economic } \\
\text { growth did not have a significant effect } \\
\text { on inflation. }\end{array}$ \\
\hline $\begin{array}{l}\text { Roşoiu } \\
\text { (2015) }\end{array}$ & $\begin{array}{l}\text { 1998:Q1-2014:Q1 } \\
\text { Romania }\end{array}$ & $\begin{array}{c}\text { Granger causality } \\
\text { test }\end{array}$ & $\begin{array}{l}\text { A bidirectional causality relation was } \\
\text { found between government expenditure } \\
\text { and economic growth, and a } \\
\text { unidirectional causality relation from } \\
\text { inflation to government expenditure and } \\
\text { economic growth was found. }\end{array}$ \\
\hline $\begin{array}{l}\text { Odhiambo } \\
\text { (2015) }\end{array}$ & $\begin{array}{l}\text { 1980-2013 } \\
\text { South Africa }\end{array}$ & $\begin{array}{l}\text { Granger causality } \\
\text { test }\end{array}$ & $\begin{array}{l}\text { Odhiambo proved that there is a } \\
\text { bidirectional causality relationship } \\
\text { between government expenditure and } \\
\text { economic growth in the short term, and a } \\
\text { unidirectional causality relationship from } \\
\text { economic growth to government } \\
\text { expenditure in the long term. }\end{array}$ \\
\hline
\end{tabular}




\begin{tabular}{|c|c|c|c|}
\hline Authors & Period / Country & Method & Results \\
\hline $\begin{array}{l}\text { Ajayi and Aluko } \\
\text { (2016) }\end{array}$ & $\begin{array}{c}\text { 1985-2014 } \\
\text { Nigeria }\end{array}$ & $\begin{array}{l}\text { Toda-Yamamoto } \\
\text { causality test }\end{array}$ & $\begin{array}{l}\text { No causal relationship was found } \\
\text { between government expenditure and } \\
\text { economic growth. }\end{array}$ \\
\hline $\begin{array}{l}\text { Sáez et al. } \\
\text { (2017) }\end{array}$ & $\begin{array}{l}1994-2012 \\
15 \text { EU member } \\
\text { countries }\end{array}$ & $\begin{array}{l}\text { Regression and } \\
\text { panel data analysis }\end{array}$ & $\begin{array}{l}\text { As a result of the analysis, the effect of } \\
\text { government expenditure on economic } \\
\text { growth in Portugal and the United } \\
\text { Kingdom was found to be positive. In } \\
\text { addition, there was a positive effect in } \\
\text { France, Greece and Luxembourg. In } \\
\text { Austria, Germany, Denmark, Finland, } \\
\text { Italy and Sweden, they found that the } \\
\text { effect of government expenditure on } \\
\text { economic growth was negative. On the } \\
\text { other hand, they also found negative } \\
\text { effects in Belgium, Ireland, the } \\
\text { Netherlands and Spain. }\end{array}$ \\
\hline $\begin{array}{c}\text { Dudzeviciute et } \\
\text { al. } \\
\text { (2018) }\end{array}$ & $\begin{array}{l}1995-2015 \\
\text { EU member countries }\end{array}$ & $\begin{array}{c}\text { Granger causality } \\
\text { test }\end{array}$ & $\begin{array}{l}\text { While a unilateral causal relationship } \\
\text { from economic growth to government } \\
\text { expenditure was found in France, } \\
\text { Belgium, Germany, Portugal and } \\
\text { Cyprus, and a unilateral causal } \\
\text { relationship from government } \\
\text { expenditure to economic growth in } \\
\text { Sweden and Slovakia, no causality } \\
\text { relationship was found between } \\
\text { government expenditure and economic } \\
\text { growth in Poland. }\end{array}$ \\
\hline $\begin{array}{c}\text { Sriyalatha and } \\
\text { Torii } \\
(2019)\end{array}$ & $\begin{array}{c}\text { 1972-2017 } \\
\text { Singapore and } \\
\text { Sri Lanka }\end{array}$ & $\begin{array}{c}\text { ARDL analysis and } \\
\text { Toda-Yamamoto } \\
\text { Granger causality } \\
\text { test }\end{array}$ & $\begin{array}{l}\text { They found that government expenditure } \\
\text { had a positive and significant effect on } \\
\text { economic growth. A bidirectional } \\
\text { causality relationship was found between } \\
\text { the inflation rate and economic growth in } \\
\text { Singapore. While inflation rate in } \\
\text { Singapore has a positive effect on } \\
\text { economic growth, it has a negative effect } \\
\text { in Sri Lanka. }\end{array}$ \\
\hline $\begin{array}{l}\text { Mandala } \\
\text { (2020) }\end{array}$ & $\begin{array}{l}\text { 1981-2018 } \\
\text { Indonesia }\end{array}$ & $\begin{array}{l}\text { Engel-Granger } \\
\text { cointegration test } \\
\text { and ECM }\end{array}$ & $\begin{array}{l}\text { Mandala found that while the } \\
\text { relationship between inflation and } \\
\text { economic growth was negative, the } \\
\text { relationship between government } \\
\text { expenditure and economic growth was } \\
\text { positive. }\end{array}$ \\
\hline
\end{tabular}

\section{Data and Method}

9 OECD member countries (France, Germany, Italy, United Kingdom, Portugal, Hungary, Spain, Finland and Poland) were randomly selected to investigate the relationship between public expenditure, inflation and economic growth. The analysis was made by employing the panel causality method. Annual data covering the period 20102019 were used. General government expenditure was taken as public expenditure. Differences in general government expenditure show the diversity of approach of countries to offer public goods and services and provide social protection. Total government expenditure per capita data was obtained from the electronic data distribution 
site of the OECD site and its logarithm was used as it is of great value. The annual percentage growth of GDP was taken as the economic growth data. And consumer price index was taken as inflation. Economic growth and inflation data were obtained from the electronic data distribution site of the World Bank website.

\subsection{Panel Unit Root Tests}

Performing unit root test in time series studies is becoming widespread among applied researchers and it becomes important for results to come out as significant in econometric analysis. In the literature relating to panel unit root tests various panel unit root tests have been developed such as Quah (1994), Harris and Tzavalis (1999), Im, Pesaran and Shin (2003), Maddala and Wu (1999), Choi (2001), Levin, Lin and Chu (2002), Harris and Sollis (2003) (Baltagi and Kao, 2000: 2).

Apart from these, Bhargava, Franzini and Narendranathan, Boumahdi and Thomes, Breitung and Meyer and Puali proposed a new test in dynamic models with fixed effects. In their proposal, they proposed Durbin Watson statistics as a new modified form of test statistics based on fixed effect residuals and differentiated OLS residuals. They proposed their own DW statistics as N goes to infinity in micro panels. Other than these, Quah suggested that the $\mathrm{N} / \mathrm{T}$ ratio is constant, the unit root test in the panel data model where the $\mathrm{N}$ and $\mathrm{T}$ values go to infinity and where they have no constant effects (Quah, 1994).

In our study, the stationarity of variables was determined by the stationarity tests developed by Levin, Lin and Chu (LLC), Im, Pesaran and Shin (IPS), ADF and PP. Of these tests, which are among the first generation stationarity tests, all tests showed the government expenditure (GE), inflation (CPI) and economic growth (GDP) series were stationary at the 1 st difference, at the significance level of $5 \%$, for LLC, IPS, ADF-Fisher, ADF and PP-Fisher tests. The stationarity tests of the series are given in Table 2.

Table 2. Panel Unit Root Tests

\begin{tabular}{|c|c|c|c|c|c|}
\hline \multirow[b]{2}{*}{ Variables } & \multirow[b]{2}{*}{ Method } & \multicolumn{2}{|c|}{ I(0) (w/constant) } & \multicolumn{2}{|c|}{ I(1) (w/constant $)$} \\
\hline & & Statistic & Prob* & Statistic & Prob* \\
\hline \multirow{4}{*}{ LGE } & Levin, Lin and Chu $\mathrm{t}^{*}$ & 6.227 & 1.000 & -7.171 & $0.000 *$ \\
\hline & Im, Pesaran and Shin W-stat & 6.811 & 1.000 & -2.741 & $0.003 *$ \\
\hline & ADF-Fisher Chi-square & 0.565 & 1.000 & 39.051 & $0.002 *$ \\
\hline & PP-Fisher Chi-square & 0.248 & 1.000 & 34.554 & $0.010^{*}$ \\
\hline \multirow{4}{*}{ GDP } & Levin, Lin and Chu $\mathrm{t}^{*}$ & -5.165 & $0.000^{*}$ & -12.139 & $0.000 *$ \\
\hline & Im, Pesaran and Shin W-stat & -2.078 & $0.018^{*}$ & -5.196 & $0.000^{*}$ \\
\hline & ADF-Fisher Chi-square & 32.299 & $0.020^{*}$ & 64.384 & $0.000 *$ \\
\hline & PP-Fisher Chi-square & 18.888 & 0.398 & 42.203 & $0.001 *$ \\
\hline \multirow{4}{*}{ CPI } & Levin, Lin and Chu $\mathrm{t}^{*}$ & -8.519 & $0.000^{*}$ & -5.707 & $0.000 *$ \\
\hline & Im, Pesaran and Shin W-stat & -3.387 & $0.000^{*}$ & -2.526 & $0.005^{*}$ \\
\hline & ADF-Fisher Chi-square & 46.474 & $0.000^{*}$ & 38.366 & $0.003 *$ \\
\hline & PP-Fisher Chi-square & 12.508 & 0.819 & 35.875 & $0.007 *$ \\
\hline
\end{tabular}

* Im, Pesaran and Shin; ADF-Fisher and PP-Fisher- Null Hypothesis: Unit root (Individual unit root process), Levin, Lin and Chu Test- Null Hypothesis: Unit root (Common unit root process). Automatic lag lenght selection based on Modified Schwarz Criteria and Bartlett Kernel. 


\subsection{Granger Causality Test}

Panel causality test is based on the Granger (1969) method. Dumitrescu and Hurlin (2012) provide an extension designed to detect causality in panel data. The underlying regression are;

$$
\begin{aligned}
& \Delta L G E_{1 t}=\alpha_{11}+\sum_{l=1}^{p_{1}} \beta_{11 l} \Delta L G E_{1 t-l}+\sum_{l=1}^{p_{1}} \delta_{11 l} \Delta G D P_{1 t-l}+\sum_{l=1}^{p_{1}} \varphi_{11 l} \Delta C P I_{1 t-l}+\varepsilon_{11 t} \\
& \Delta L G E_{N t}=\alpha_{1 N}+\sum_{l=1}^{p_{1}} \beta_{1 N l} \Delta L G E_{N t-l}+\sum_{l=1}^{p_{1}} \delta_{1 N l} \Delta G D P_{N t-l}+\sum_{l=1}^{p_{1}} \varphi_{1 N l} \Delta C P I_{N t-l}+\varepsilon_{1 N t} \\
& \Delta G D P_{1 t}=\alpha_{21}+\sum_{l=1}^{p_{2}} \beta_{21 l} \Delta G D P_{1 t-l}+\sum_{l=1}^{p_{2}} \delta_{21 l} \Delta L G E_{1 t-l}+\sum_{l=1}^{p_{2}} \varphi_{21 l} \Delta C P I_{1 t-l}+\varepsilon_{21 t} \\
& \Delta G D P_{N t}=\alpha_{2 N}+\sum_{l=1}^{p_{2}} \beta_{2 N l} \Delta G D P_{N t-l}+\sum_{l=1}^{p_{2}} \delta_{2 N l} \Delta L G E_{N t-l}+\sum_{l=1}^{p_{2}} \varphi_{2 N l} \Delta C P I_{N t-l}+\varepsilon_{2 N t} \\
& \Delta C P I_{1 t}=\alpha_{31}+\sum_{l=1}^{p_{3}} \beta_{31 l} \Delta C P I_{1 t-l}+\sum_{l=1}^{p_{3}} \delta_{31 l} \Delta G D P_{1 t-l}+\sum_{l=1}^{p_{3}} \varphi_{31 l} \Delta L G E_{1 t-l}+\varepsilon_{31 t} \\
& \Delta C P I_{N t}=\alpha_{3 N}+\sum_{l=1}^{p_{3}} \beta_{3 N l} \Delta C P I_{N t-l}+\sum_{l=1}^{p_{3}} \delta_{3 N l} \Delta G D P_{N t-l}+\sum_{l=1}^{p_{3}} \varphi_{3 N l} \Delta L G E_{N t-l}+\varepsilon_{3 N t}
\end{aligned}
$$

In the above equations, " $N$ " denotes the number of countries in the panel $(\mathrm{i}=1,2,3, \ldots, N)$, " $\mathrm{t}$ " the time period $(\mathrm{t}=$ $1,2,3, \ldots, \mathrm{T})$ and "l" the length of the lag. The error terms . $\varepsilon 1 \mathrm{Nt}, \varepsilon 2 \mathrm{Nt}, \varepsilon 3 \mathrm{Nt}$ are assumed to be white noise (they have zero mean and constant variance).

Granger causality test results according to 2 lags are given in Table 3.

Table 3. Granger Causality Test

\begin{tabular}{|l|c|c|c|}
\hline Null hypothesis: & Obs & F-Statistic & Prob \\
\hline$\Delta$ GDP does not Granger cause $\Delta$ CPI & 63 & 4.040 & $0.022^{*}$ \\
$\Delta$ CPI does not Granger cause $\Delta$ GDP & 4.500 & $0.015^{*}$ \\
\hline$\Delta$ LGE does not Granger cause $\Delta$ CPI & 63 & 1.807 & 0.173 \\
$\Delta$ CPI does not Granger cause $\Delta$ LGE & & 7.288 & $0.001^{*}$ \\
\hline$\Delta$ LGE does not Granger cause $\Delta$ GDP & 63 & 7.499 & $0.001^{*}$ \\
$\Delta$ GDP does not Granger cause $\Delta$ LGE & & 0.082 & 0.921 \\
\hline
\end{tabular}

According to the test results in Table 3, the H0 hypothesis, which states that GDP does not Granger-cause CPI, is rejected at the 5\% significance level the H0 hypothesis, which states that CPI does not Granger-cause GDP, is rejected at the 5\% significance level. According to the Granger causality test, a bidirectional causality relationship between inflation and economic growth has been determined. The H0 hypothesis, which states that CPI does not Granger-cause GE, is rejected at the 5\% significance level. A unidirectional causality relationship was found from inflation to government expenditure. The H0 hypothesis, which states that GE does not Granger-cause GDP, is rejected at the 5\% significance level. A unidirectional causality relationship was found from government expenditure to economic growth.

\section{Conclusion}

The state's role in the economy has been discussed in the economic literature for a long time. While many schools, starting from the classical economists, advocated that the state should not intervene in the economy, many schools which adopted Keynesian view and are close to Keynesian view have argued that the state should intervene in the economy with monetary and fiscal policies. Although the state's intervention in the economy has increased in some periods and decreased in some, it is seen that the state has an important role in the economic system in economies. Governments use monetary and fiscal policies effectively to achieve their macroeconomic goals. Government expenditure is one of the important fiscal policy tools used by governments to achieve macroeconomic goals. In the economy, changes in government expenditures cause changes in demand on the one hand and in investments on the other. And changes in demand and investments in the economy have impact both on the economic growth, by affecting the production output, and on inflation. The relationship between public sector expenditures and economic growth is explained in the context of the hypotheses set forth by Wagner and Keynes in the economic literature. While Wagner argues that as the economic growth increases, the expenditures made by the public sector would increase, Keynes argues that the increase in the expenditures made by the public sector would increase the economic growth. Additionally, according to the Keynesian view, expenditures made by the public sector increase 
the demand for goods and services in the economy and cause an increase in aggregate demand. As a result of the increase in demand for goods and services, the prices of goods and services increase and an increase is observed in the general level of prices in the economy. This causes inflation arising from demand.

The change in expenditures made by the public sector affects macroeconomic variables that are deemed important such as economic growth and inflation. Therefore, in this study, how government expenditure affects these two macroeconomic variables in 9 randomly selected OECD countries was analyzed by panel causality method using annual data for the period 2010-2019. As a result of the analysis, a bidirectional causality relationship was found between economic growth and inflation in the period analyzed. It has been also determined that there is a unidirectional causality relationship from inflation to government expenditure and from government expenditure to economic growth.

The finding of a unidirectional causal relationship from government expenditure to economic growth supports that the Keynesian view holds true in selected countries in the relevant period. It was found that there was a unidirectional relationship from inflation to government expenditure. According to this finding, when there is an inflationary process in the economy, the government has to implement a contractionary fiscal policy in order to reduce the inflation and for this, the aggregate demand in the economy is tried to be reduced by decreasing government expenditures. Another finding is that there is a bidirectional causality relationship between economic growth and inflation. Due to the increase in the amount of goods and services produced as a result of economic growth, more people will be employed. As a result of the increase in employment in the economy, there will be an increase in people's incomes. People will spend more on goods and services in the economy with their increasing incomes. Prices of goods and services will increase depending on the increase in demand for goods and services. An increase in the general level of prices in the economy will be seen. This will lead to inflation in the economy arising from demand. From the findings obtained as a result of the analysis, it can be stated that effective use of government expenditures can affect economic growth positively and government expenditures can be used as a policy tool in controlling inflation. Governments should be very careful when making government expenditure. While they want to achieve economic growth, they should be careful that their government expenditures do not cause inflation. Governments can apply additional monetary and fiscal policies in addition to government expenditure to prevent inflation in the economy.

\section{References}

AJAYI, M. A. and ALUKO, O. A. (2016). The Causality between Government Expenditure and Economic Growth in Nigeria: A Toda-Yamamoto Approach. Journal of Economics and Business Research, 22(2), 77-90.

ALEXIOU, C. (2009). Government expenditure and Economic Growth: Econometric Evidence from the South Eastern Europe (SEE). Journal of Economic and Social Research, 11(1), 1-16.

ALQADI, M. and ISMAIL, S. (2019). Government expenditure and Economic Growth: Contemporary Literature Review. Journal of Global economics, 7(4), 1-4.

ATTARI, M. I. J. and JAVED, A. Y. (2013). Inflation, Economic Growth and Government Expenditure of Pakistan: 1980-2010. Procedia Economics and Finance, 5, 58 - 67.

BALtAGI, B. H. and KAO, C. (2000). Nonstationary Panels, Cointegration in Panels and Dynamic Panels: A Survey. Center for Policy Research Working Papers, 16.

BASHIR, F., NAWAZ, S., YASIN, K., KHURSHEED, U., KHAN, J. and QURESHI, M. J. (2011). Determinants of Inflation in Pakistan: An Econometric Analysis Using Johansen Co-Integration Approach. Australian Journal of Business and Management Research, 1(5), 71-82.

CHENG, B. S. and LAI, T. W. (1997). Government Expenditures and Economic Growth in South Korea: A VAR Approach. Journal of Economic Development, 22(1), 11-24.

CHOI, I. (2001). Unit Root Tests for Panel Data. Journal of International Money and Finance, 20(2), $249-272$.

DUDZEVICIUTE, G., ŠIMELYTE, A. and LIUCVAITIENE, A. (2018). Government Expenditure and Economic Growth in the European Union Countries, International Journal of Social Economics, 45(2), 372-386.

DUMITRESCU, E. I. and HURLIN, C. (2012). Testing for Granger Non-Causality in Heterogeneous Panels. Economic Modelling. 29(4), 1450-1460.

FRANK, A., JOSEPH, O. M. and ACKAH, I. (2014). Government Expenditures and Economic Growth Dynamics in Ghana. International Journal of Economics and Empirical Research, 2(5), 180- 190.

GRANGER, C. W. J. (1969). Investigating Causal Relations by Econometric Models and Cross-Spectral Methods. Econometrica, 37(3), 424-438. 
Finans Ekonomi ve Sosyal Araştırmalar Dergisi, Cilt.6 Sayı.3, Eylül 2021

HARRIS, R. D. F. and TZAVALIS, E. (1999). Inference for Unit Roots in Dynamic Panels Where the Time Dimension is Fixed. Journal of Econometrics, 91(2), 201-226.

HARRIS, R. and SOLLIS, R. (2003). Applied the Time Series Modelling and Forecasting. England: Wiley.

HUANG, C. J. (2006). Government Expenditures in China and Taiwan: Do They Follow Wagner's Law? Journal of Economic Development, 31(2), 139-148.

IM, K. S., PESARAN, M. H. and SHIN, Y. (2003). Testing for Unit Roots in Heterogeneous Panels. Journal of Econometrics, 115(1), 53-74.

JIRANYAKUL, K. and BRAHMASRENE, T. (2007). The Relationship Between Government Expenditures and Economic Growth in Thailand. Journal of Economics and Economic Education Research, 8(2), 1-9.

KOLLURI, B. R., PANIK, M. J. and WAHAB, M. S. (2000). Government Expenditure and Economic Growth: Evidence from G7 Countries. Applied Economics, 32(8), 1059-1068.

LAHIRUSHAN, K. P. K. S. and GUNASEKARA, W. G. V. (2015). The Impact of Government Expenditure on Economic Growth: A Study of Asian Countries. International Journal of Social, Behavioral, Educational, Economic, Business and Industrial Engineering, 9(9), 3152-3160.

LEVIN, A., LIN, C. F. and CHU, C. S. J. (2002). Unit Root Tests in Panel Data: Asymptotic and Finite-Sample Properties. Journal of Econometrics, 108(1), 1-24.

LOIZIDES, J. and VAMVOUKAS, G. (2005). Government Expenditure and Economic Growth: Evidence from Trivariate Causality Testing. Journal of Applied Economics, 8(1), 125-152.

MADDALA, G. S. and WU, S. (1999). A Comparative Study of Unit Root Tests with Panel Data and a New Simple Test. Oxford Bulletin of Economics and Statistics, 61(1), 631- 652.

MANDALA, R. A. M. (2020). Inflation, Government Expenditure and Economic Growth in Indonesia. Jambura Equilibrium Journal (JEJ), 2(2), 109-118.

MEHRARA, M. and SUJOUDI, A. (2015). The Relationship between Money, Government expenditure and Inflation in the Iranian Economy. International Letters of Social and Humanistic Sciences, 51, 89-94.

MOHAMMAD, S. D., WASTI, S. K. A., LAL, I. and HUSSAIN, A. (2009). An Empirical Investigation between Money Supply, Government Expenditure, Output \& Prices: The Pakistan Evidence. European Journal of Economics, Finance and Administrative Sciences, 17, 60-68.

ODHIAMBO, N. M. (2015). Government Expenditure and Economic Growth in South Africa: An Empirical Investigation. Atlantic Economic Journal, 43(3), 393-406.

OLAYUNGBO, D. O. (2013). Government expenditure and Inflation in Nigeria: An Asymmetry Causality Test. International Journal of Humanities and Management Sciences, 1(4), 238-242.

ONO, H. (2014). The Government Expenditure-Economic Growth Relation in Japan: An Analysis by Using the ADL Test for Threshold Cointegration. Applied Economics, 46(28), 3523-3531.

QUAH, D. (1994). Exploiting Cross Section Variation for Unit Root Inference in Dynamic Data. Economics Letters, 44(1-2), 9-19.

ROSOIU, I. (2015). The Impact of the Government Revenues and Expenditures on the Economic Growth. Procedia Economics and Finance, 32, 526-533.

SÁEZ, M. P. and ÁLVAREZ-GARCIA, S. (2006). Government expenditure and Economic Growth in the European Union Countries: An Empirical Approach. SSRN Electronic Journal, 1-11.

SÁEZ, M. P., ÁLVAREZ-GARCIA, S. and RODRIGUEZ, D. C. (2017). Governmen Expenditure and Economic Growth in the European Union Countries: New evidence. Bulletin of Geography Socio-Economic Series, $36,127-133$.

SRIYALATHA, M. A. K. and TORII, H. (2019). Impact of Fiscal Policy on Economic Growth: A Comparison between Singapore and Sri Lanka. Kelaniya Journal of Management, 8(1), 37-56.

TABAN, S. (2010). An Examination of the Government expenditure and Economic Growth Nexus for Turkey Using the Bound Test Approach. International Research Journal of Finance and Economics, 48, 187-196.

THABANE, K. and LEBINA, S. (2016). Economic Growth and Government expenditure Nexus: Empirical Evidence from Lesotho. African Journal of Economic Review, 4(1), 86-100. 